\title{
TEACHERS' PERCEPTIONS OF SCAFFOLDING EFL STUDENTS' READING COMPREHENSION AT HIGH SCHOOLS IN THE MEKONG DELTA, VIETNAM
}

\author{
Chau Ngoc Tran', \\ Huan Buu Nguyen ${ }^{2 i}$ \\ ${ }^{1} \mathrm{Ca}$ Mau Vietnam-Korea Vocational College, \\ Vietnam \\ ${ }^{2}$ Can Tho University, \\ Vietnam
}

\begin{abstract}
Scaffolding has held great appeal for teachers of English as a foreign language (EFL) and scholars in helping students take greater responsibility or ownership in their language learning and reach academic success. However, little is known about how teachers perceived this type of support as improving students' reading comprehension in English within the teaching and learning context in Vietnam high schools. This paper therefore reports a descriptive study that explored teachers' perceptions of scaffolding EFL students' reading comprehension at high schools in the Mekong Delta, Vietnam. Questionnaires and semi-structured interviews were employed to collect data from seventy-nine high school teachers. The findings provide insightful views into teachers' perceptions about scaffolding students' reading comprehension. The findings also reveal how teachers experienced varying degrees of their perceptions of scaffolding and challenges while delivering their scaffolding practices in reading instruction.
\end{abstract}

Keywords: teachers' perceptions, scaffolding, reading comprehension

\section{Introduction}

Several studies have documented the role of scaffolding it plays in helping students gain control of their learning and enhance their understanding of particular text passages (Gibbons, 2015). In other words, scaffolding refers to the concept of support by the teacher or more capable peers to release students from teacher authority and allow students the opportunity to take greater responsibility for their own learning process (e.g., Hong \& Nguyen, 2019; Reed \& Railsback, 2003). In particular, scaffolding has been widely held as an effective teaching tool for improving reading of English language

i Correspondence: email nbhuan@ctu.edu.vn 
students (McKenzie, 2001). Significant reforms in higher education in Vietnam have highlighted the importance of using English across the schools and particularly, the need to increase the quality of language teaching and learning English to keep up with the growing needs of students in the global integration (Ministry of Education and Training, 2008). However, in the context of reading instruction at Vietnamese high schools where traditional lecturing is still predominant, while teachers acted their roles in their teaching practices as decision-makers, students were given little exposure to process or digest information presented to them (Hong \& Nguyen, 2019). In addition, despite the positive impact of scaffolding on reading comprehension documented in the literature (e.g., Belland, 2014; Gibbons, 2015; Proctor, Dalton, \& Grisham, 2007; Reynolds \& Daniel, 2018), there is a paucity of research into teachers' perceptions of scaffolding students' reading comprehension, in teaching and learning contexts at high schools in the Mekong Delta, Vietnam. This current study, thus, examines this area of interest. The research question that guided the study reported in this paper was, "What are teachers' perceptions of scaffolding students' reading comprehension?"

\section{Literature review}

The following section reviews the literature on perceptions, reading comprehension, and scaffolding with regard to how these were defined for this study.

\subsection{Perceptions}

There are several views of the term 'perceptions' in the literature. Perceptions are defined as the ability of individuals to recognize and understand information or the world around us through the use of senses (Richards \& Schmidt, 2010; Ward, Grinstein, \& Keim, 2015). Another view is that perceptions are associated with the process of relating the meaning of information to experience (Eggen \& Kauchak, 2001). In other words, perceptions refer to a process of recognizing and interpreting information or an experience-based process of information. Therefore, teachers' perceptions play an important part in the teaching process with regard to thinking, selecting and making sense of information provided to learners or students (․ G. T. Nguyen \& Nguyen, 2019; T. C. Nguyen \& Nguyen, 2020). For the purposes of this current study, the term 'teachers' perceptions' refers to teachers' thinking about what they are going to do or their awareness of doing things in their teaching practices.

\subsection{Reading comprehension}

There are several views of reading comprehension in the literature. Reading is defined as a process that readers decode text messages by using linguistic knowledge (Bernhardt, 2011; Grabe, 2009). Others view reading as a process of understanding meanings of a printed material or texts through readers' knowledge (Snow, 2002). This implies that reading is a process of making sense of meaning between the reader and the text (Nuttall, $\underline{2005}$ ). Thus, reading is not a linear process; rather, it is interactive process because readers 
form hypotheses and use their knowledge to construct meaning (Israel \& Duffy, 2009). In other words, reading is conceptualized as a sophisticated and interactive process between the reader, the text, and the writer's message or meaning (Nuttall, 2005; Pearson, 2009). Taken all perspectives together, reading comprehension is a dynamic and interactive process of constructing the meaning of a specific text passage based on students' prior knowledge and new knowledge. From the sociocultural perspective, one way to help students improve their reading comprehension and become active and independent readers is through scaffolding (

\subsection{Scaffolding}

\subsubsection{Scaffolding}

The term 'scaffolding' is widely researched in English language teaching and learning with particular regard to enhancing students' higher-order thinking abilities and successful learning of reading contents (Belland, 2014; Rodgers, 2017; Wood, Bruner, \& Ross, 1976). In the educational setting, scaffolding was first developed by Wood, Bruner, and Ross (1976) who undertook a study on parent-child talk. As a metaphor in teaching and learning, these authors claim that scaffolding is a process in which a child is unable to solve a problem or accomplish a given task or reach a goal that goes beyond his unassisted work. This is rooted in Vygotsky's (1978) sociocultural theory of learning as it refers to a temporary support from a more knowledgeable peer or more capable person by which students can complete their work which would be beyond their endeavors. These lines of reasoning suggest that once students can accomplish a given task, scaffolding is likely to remove or become faded since students can become independent (Ankrum, Genest, \& Belcastro, 2014; Reynolds \& Daniel, 2018; Walqui, 2006). Other researchers associate scaffolding with the concept of Zone of Proximal Development (ZPD) (e.g., Booth, 2012; Rodgers, 2017; Salem, 2017). ZPD is viewed as "the distance between the actual developmental level as determined by independent problem solving and the level of potential development as determined through problem solving under adult guidance or in cooperation with more capable peers" (Vygotsky, 1978, p. 86). This social view of teaching and learning suggests that learning takes place through interaction or collaboration between the teacher and students. Students are assumed to act as active participants in their learning process (Gibbons, 2015). In addition, from the Vygotskian perspective, knowledge is co-constructed under the guidance of or in collaboration with more knowledgeable peers, rather than individually constructed.

Another perspective is that scaffolding is a temporary support provided by the teacher to their students in order to move them to a new level of understanding and become autonomous while completing a specific task (Rodgers, 2017; Salem, 2017). These conceptualizations stress the role of support, collaboration, and interaction in relation to effective teaching over student learning (Hong \& Nguyen, 2019).

Drawn on the above perspectives, scaffolding is defined, for the purposes of this study, as the support given by the teacher to students who can accomplish a particular 
learning activity with increased understanding from which they take greater responsibility for building up their knowledge.

\subsubsection{Scaffolding reading comprehension}

Scaffolding has evolved in the educational area as a process of instructional support and transfer of responsibility from the teacher to students (van de Pol, Volman, \& Beishuizen, 2010). Thus, with this supportive learning environment, scaffolding is known as influencing and fostering students' reading comprehension (Enyew \& Yigzaw, 2015; Gibbons, 2015). According to Gibbons (2015), the teacher scaffolds students' reading by getting students involved in reading activities through three common stages: before, during and after reading (Herawati, Gani, \& Muslim, 2020). These are delineated as planning, application, and comprehension check of a reading text. In the planning stage, the teacher provides students with the opportunity to build on their prior knowledge and take on new knowledge. In the second stage, as a result of planning to read, students are encouraged to use strategies that promote interaction with a given reading task or text. In the third stage, students are asked to relate their understanding or comprehension of the text to other aspects or skills of English.

\section{Methodology}

The study took place over a fifteen-week semester period during academic year (20202021). A descriptive study using a mixed-method approach was employed to explore perceptions of high school teachers in the Mekong Delta of scaffolding reading comprehension of English as a foreign language (EFL). The mixed-methods approach incorporating quantitative and qualitative data collection and analysis was used to gain insights into teachers' views of the topic under investigation than does the use of either approach alone (Fraenkel, Wallen, \& Hyun, 2012).

For the quantitative approach, a questionnaire was adapted from Hong and Nguyen's (2019) questionnaire. The twenty-two item-questionnaire consists of threesections. The first section focuses on teachers' demographic information regarding gender, age, and years of experience in teaching English. The second section includes teachers' understanding of scaffolding and its importance in teaching reading. The third section is centered on teachers' perceptions of the benefits and challenges of scaffolding students' reading comprehension. To complement the qualitative data, semi-structured interviews were conducted with six participating teachers to gain insights into their perceptions of scaffolding students' reading comprehension.

Participants in this study were 79 teachers who were teaching at different high schools in the Mekong Delta. Of this sample, 17 teachers were males $(21,5 \%)$ and 62 teachers were females $(78,5 \%)$. Their ages range from 22 to 40 . Of the total, 15 teachers were in 22-30 age group (19\%), 34 teachers in $31-40$ age group (43\%); and 30 in the group of over 40 years old $(38 \%)$. 
The participant selection was based on convenience sampling (Fraenkel et al., 2012). This sampling aimed at the number of teachers who were available and accessible at high schools in the community and it allowed for easy administration of the data collection. At the time of the study, the range of the teachers' overall teaching experience was 1 to 10 years. Eight teachers were between one and five years' experience, 17 between six and ten years' experience, and 54 from more than 10 years' experience.

The questionnaire items and interview questions were checked for clarity of the content and consistency by the supervisor. The quantitative data from the questionnaire were statistically analyzed using an SPSS (Statistical Package for Social Sciences) version 20. The reliability of the piloted questionnaire delivered to 36 teachers was confirmed with the Cronbach's alpha at .916. All interview responses were recorded, transcribed, and translated from Vietnamese to English for data analysis. The interview transcripts were handed-coded using thematic analysis (Boyatzis, 1998). The pilot interview allowed for the validity of the questions and their constructs (Lapan \& Quartaroli, 2009), review and refinement of the content and additional information with regard to the length of time spent in the interview process in preparation for the actual interviews $(\underline{H}$. B. Nguyen, 2014).

\section{Findings}

This section presents the findings to the research question about teachers' perceptions of scaffolding students' reading comprehension at high schools in the Mekong Delta, Vietnam. The findings indicate that most participating teachers expressed their conceptual understanding at a high level and perceived scaffolding students' reading comprehension as useful, as illustrated in the following sections.

\subsection{Findings from the questionnaires}

\subsubsection{Teachers' understanding of scaffolding}

Section Two of the questionnaire of seven items presents teachers' understanding of scaffolding and its importance to students' reading comprehension, as shown in Table 4.1.

Table 4.1: Teachers' understanding of scaffolding and its importance

\begin{tabular}{|c|c|c|c|c|c|c|}
\hline \multirow[t]{2}{*}{ Items } & \multicolumn{2}{|c|}{$\begin{array}{c}\text { Strongly } \\
\text { disagree \& } \\
\text { Disagree }\end{array}$} & \multicolumn{2}{|c|}{ Neutral } & \multicolumn{2}{|c|}{$\begin{array}{c}\text { Strongly } \\
\text { agree \& } \\
\text { Agree }\end{array}$} \\
\hline & $F$ & $\mathbf{P}$ & $\mathbf{F}$ & $\mathbf{P}$ & $F$ & $\mathbf{P}$ \\
\hline $\begin{array}{l}\text { 1. Scaffolding is the guide from the teacher to help } \\
\text { students complete a reading task step by step. }\end{array}$ & 3 & $3.8 \%$ & 6 & $7.6 \%$ & 70 & $88.6 \%$ \\
\hline $\begin{array}{l}\text { 2. Scaffolding is the assistance by the teacher to } \\
\text { facilitate student learning of reading. }\end{array}$ & 0 & $0.0 \%$ & 6 & $7.6 \%$ & 73 & $92.6 \%$ \\
\hline $\begin{array}{l}\text { 3. Scaffolding is a useful approach to support } \\
\text { students in completing a reading task. }\end{array}$ & 6 & $7.6 \%$ & 6 & $7.6 \%$ & 59 & $84.8 \%$ \\
\hline
\end{tabular}




\begin{tabular}{lllllllr}
\hline \hline 4. & $\begin{array}{l}\text { Scaffolding is to enable students to deal with a } \\
\text { complex reading task. }\end{array}$ & 6 & $7.6 \%$ & 16 & $20.3 \%$ & 57 & $72.1 \%$ \\
\hline 5. & $\begin{array}{l}\text { Scaffolding is to help students understand their } \\
\text { reading lesson better. }\end{array}$ & 5 & $6.4 \%$ & 16 & $20.3 \%$ & 58 & $73.4 \%$ \\
\hline 6. & $\begin{array}{l}\text { Scaffolding is to help students to solve problems } \\
\text { in their reading task. }\end{array}$ & 0 & $0.0 \%$ & 6 & $7.6 \%$ & 73 & $92.4 \%$ \\
\hline 7. & $\begin{array}{l}\text { Scaffolding is useful for students to understand } \\
\text { the reading topic. }\end{array}$ & 1 & $1.3 \%$ & 14 & $17.7 \%$ & 64 & $81.0 \%$ \\
\hline
\end{tabular}

Note: $\mathrm{F}=$ Frequency; $\mathrm{P}=$ Percentage

Table 4.1 shows that the teachers were more aware of the term 'scaffolding' (Items 1, 2, 3 ). Most teachers ( $n=73$ ) agreed that scaffolding is teachers' assistance to facilitate student learning (Item 2$) .88 .6 \%$ of teachers $(n=70)$ said that scaffolding is the guide from the teacher to help students complete a particular task step by step. $84.8 \%$ of the participants $(n=59)$ agreed that scaffolding is a useful approach to support students in completing a reading task (Item 3). With regard to the importance of scaffolding, 92,4\% of the teachers $(n=73)$ agreed that scaffolding is to facilitate students to solve problems in their tasks (Item 6), $81.0 \%$ of the participants thought scaffolding is useful for students to understand the reading topic (Item 7). And more than $70 \%$ of the teachers agreed that scaffolding is to enable students to deal with a complex reading task, and understand their reading lesson better (Items 4, 5).

\subsubsection{Teachers' perceptions about the benefits of scaffolding}

A Frequency Test was used to examine how teachers perceived the benefits of scaffolding students' reading comprehension, as shown in Table 4.3 (Items 8-19).

Table 4.3: Frequency test of teachers' perceptions about the benefits of scaffolding

\begin{tabular}{|c|c|c|c|c|c|c|}
\hline \multirow[t]{2}{*}{ Items } & \multicolumn{2}{|c|}{$\begin{array}{l}\text { Strongly } \\
\text { disagree \& } \\
\text { Disagree }\end{array}$} & \multicolumn{2}{|c|}{ Neutral } & \multicolumn{2}{|c|}{$\begin{array}{l}\text { Strongly } \\
\text { agree \& } \\
\text { Agree }\end{array}$} \\
\hline & $\mathbf{F}$ & $\mathbf{P}$ & $\mathbf{F}$ & $\mathbf{P}$ & $F$ & $\mathbf{P}$ \\
\hline $\begin{array}{l}\text { 8. I think scaffolding gets students involved in } \\
\text { reading. }\end{array}$ & 3 & $3.8 \%$ & 11 & $13.9 \%$ & 65 & $82.3 \%$ \\
\hline $\begin{array}{l}\text { 9. I think scaffolding helps students to do the task } \\
\text { easier. }\end{array}$ & 0 & $0.0 \%$ & 5 & $6.3 \%$ & 74 & $93.6 \%$ \\
\hline $\begin{array}{l}\text { 10. I think scaffolding helps reduce students' anxiety } \\
\text { to deal with the text. }\end{array}$ & 2 & $2.5 \%$ & 18 & $22.8 \%$ & 59 & $74.7 \%$ \\
\hline $\begin{array}{l}\text { 11. I think scaffolding enables students to achieve a } \\
\text { higher level of proficiency in their learning } \\
\text { process. }\end{array}$ & 2 & $2.5 \%$ & 12 & $15.2 \%$ & 65 & $82.3 \%$ \\
\hline $\begin{array}{l}\text { 12. I think scaffolding motivates students to learn } \\
\text { reading. }\end{array}$ & 2 & $2.6 \%$ & 14 & $17.7 \%$ & 63 & $79.8 \%$ \\
\hline $\begin{array}{l}\text { 13. I think scaffolding allows students to complete a } \\
\text { reading activity at different phase of the lesson. }\end{array}$ & 1 & $1.3 \%$ & 12 & $15.2 \%$ & 66 & $84.5 \%$ \\
\hline $\begin{array}{l}\text { 14. I think scaffolding makes reading classroom } \\
\text { atmosphere more interesting. }\end{array}$ & 1 & $1.3 \%$ & 33 & $41.8 \%$ & 45 & $57 \%$ \\
\hline
\end{tabular}




\begin{tabular}{llllllr}
\hline \hline $\begin{array}{l}\text { 15. I think scaffolding helps students interact with } \\
\text { the teacher. }\end{array}$ & 0 & $0.0 \%$ & 7 & $8.9 \%$ & 72 & $91.1 \%$ \\
\hline $\begin{array}{l}\text { 16. I think scaffolding helps students interact with } \\
\text { their peers. }\end{array}$ & 10 & $12.6 \%$ & 13 & $16.5 \%$ & 56 & $70.9 \%$ \\
\hline $\begin{array}{l}\text { 17. I think scaffolding helps students acquire a } \\
\text { higher level of reading. }\end{array}$ & 1 & $1.3 \%$ & 9 & $11.4 \%$ & 69 & $87.3 \%$ \\
\hline $\begin{array}{l}\text { 18. I think scaffolding helps students get the key idea } \\
\text { of the reading. }\end{array}$ & 4 & $5.1 \%$ & 17 & $21.5 \%$ & 58 & $73.4 \%$ \\
\hline $\begin{array}{l}\text { 19. I think scaffolding will be faded gradually when } \\
\text { students become more independent. }\end{array}$ & 3 & $3.8 \%$ & 17 & $21.5 \%$ & 59 & $74.7 \%$ \\
\hline
\end{tabular}

Note: $\mathrm{F}=$ Frequency; $\mathrm{P}=$ Percentage

Table 4.3 indicates that the teachers had a range of perceptions that reflected the benefits of scaffolding with regard to students' reading comprehension. Overall, the results of the test reveal that the surveyed teachers agreed on the idea that scaffolding was beneficial at a high level of agreement, except its usefulness with regard to the learning atmosphere, as reported by 45 teachers (57\%). Almost all of the teachers agreed that scaffolding helped students to do the task easier (93.6\%) and that this type of instruction could form teacherstudent interaction (91.1\%). Scaffolding was agreed by majority of the teachers in ways that it could help students get a high level of reading $(87.3 \%)$, complete a reading activity at different phase in a reading lesson (84.5\%). Responses indicated that $82.3 \%$ of the teachers felt scaffolding allowed students not only to achieve their level of proficiency in the learning process but also involve them in reading tasks. While $79.8 \%$ of the teachers felt that scaffolding could motivate students to learn reading, $74.7 \%$ of the teachers felt that scaffolding could help students reduce their anxiety to work with a text and that this type of support would be faded or removed when students could become more independent. $73.4 \%$ of the teachers thought that scaffolding could help students get the main idea of the reading, followed by $70.9 \%$ of the teachers recognized scaffolding as a way that could help students interact with peers.

A Frequency Test was carried out to investigate how teachers perceived the challenges associated with scaffolding students' reading comprehension. Table 4.4 shows the percentages of agreement and disagreement for three items, as shown in Table 4.4. (Items 20-22).

Table 4.4: Frequency test of teachers' perceptions about challenges in scaffolding

\begin{tabular}{lcccccc}
\hline \multirow{2}{*}{ Items } & \multicolumn{2}{c}{$\begin{array}{c}\text { Strongly } \\
\text { disagree \& } \\
\text { Disagree }\end{array}$} & & Neutral & \multicolumn{2}{c}{$\begin{array}{c}\text { Strongly } \\
\text { agree \& } \\
\text { Agree }\end{array}$} \\
\cline { 2 - 8 } & $\mathbf{F}$ & $\mathbf{P}$ & $\mathbf{F}$ & $\mathbf{P}$ & $\mathbf{F}$ & $\mathbf{P}$ \\
\hline $\begin{array}{l}\text { 20. I think scaffolding needs much preparation from } \\
\text { the teacher in a reading class. }\end{array}$ & 18 & $22.8 \%$ & 22 & $27.8 \%$ & 39 & $49.5 \%$ \\
$\begin{array}{l}\text { 21. I think scaffolding is problematic in mixed-ability } \\
\text { classes of reading. }\end{array}$ & 2 & $2.5 \%$ & 10 & $12.7 \%$ & 67 & $84.8 \%$ \\
22. I think scaffolding is time-consuming. & 4 & $5.1 \%$ & 16 & $20.3 \%$ & 59 & $74.7 \%$ \\
\hline
\end{tabular}

Note: $\mathrm{F}=$ Frequency; $\mathrm{P}=$ Percentage 
As shown in Table $4.4,84.8 \%$ of the teachers $(n=67)$ reported that scaffolding was a problem in mixed-ability classes of reading. $74.7 \%$ of the teachers $(n=59)$ believed scaffolding was time-consuming. Only $49.5 \%$ of the teachers $(n=39)$ thought that they needed preparation to scaffolding student learning.

\subsection{Findings from the interviews}

\subsubsection{Insights into teachers' understanding of scaffolding}

Analysis of the interview data reveals that the six participating teachers had a range of perceptions that reflected their understandings of scaffolding as a form of teacher support in English teaching in general and in reading comprehension in particular. Besides, they emphasized the importance of scaffolding in teaching reading. All of the interviewed teachers were aware of scaffolding before taking part in this study. For instance, two teachers shared their views:

"I think scaffolding is a term used to describe a way that the teacher guides his or her students to complete a reading lesson." (Diep, interview extract)

"Scaffolding is the teacher' support given to students who get the knowledge the teacher wants to convey or transfer." (Linh, interview extract)

Recognizing the importance of scaffolding, two teachers said that they became aware of scaffolding as a way that could help students gain new knowledge or reading skills in the learning process. Their views are illustrated in these following statements:

"[...] I think scaffolding will influence how students relate their knowledge they had before to read a new lesson content and improve their skills or get higher scores on exams." (Diep, interview extract)

"I believe that while leading students to the new lesson, scaffolding is extremely important. This type of instruction can help students learn new knowledge at higher order thinking." (Tran, interview extract)

The above quotes also suggest the perceived value of the support provided by the teacher who could help students think about their learning new knowledge in a more critical way or move them forward. 


\subsubsection{Insights into teachers' perceptions of benefits and challenges of scaffolding reading comprehension}

\section{A. Benefits of scaffolding}

All of the six interviewed teachers perceived that scaffolding benefited students' reading comprehension in several ways. The four themes were identified as interaction, increased students' interests, active learning atmosphere, and anxiety reduction.

\section{a. Two-way interaction}

Two teachers thought that scaffolding during the reading instruction could lead them to form the interaction between the teacher and students and student-student interaction.

"I think when students are given cue words or prompts to begin the topic of the day, they find this a good opportunity to talk with other classmates. This allows them to communicate with the teacher while answering questions for the reading unit. As a result of such interchange, students can learn more from the reading passage." (Diep, interview extract)

"I think students, while working with other classmates, have a chance to think and then come up with different ideas or opinions to answer questions. Well, this type of guidance from the teacher will be a good working process between students and teacher-student." (Tran, interview extract)

\section{b. Increased students' interest}

All of the teachers shared that scaffolding could increase students' interests in the lesson content and then improve their reading performance. The two extracts below show their views.

"[...] when I asked few questions before introducing the topic of the reading lesson, students wanted to give the answers instead of sitting silently listening to what was presented to them." (Diep, interview extract)

"[...] I think by giving students a chance to explore the answers to the reading task, it is a good way to see how they got involved in." (Linh, interview extract)

\section{c. Active learning atmosphere}

Four out of the six teachers perceived that scaffolding could make the class atmosphere more active. Their views are presented below.

"When I use pictures or games to introduce the topic, students felt good at expressing what they know or understand about this." (Vinh, interview extract) 
"Well, students liked to answer my questions from the beginning of the class. The pictures, for example, attract their attention to the use of words." (Hanh, interview extract)

\section{d. Anxiety reduction for students}

Three out of the six teachers said that scaffolding could help reduce students' anxiety while reading texts. The following extracts illustrate their views.

"Before reading, students were encouraged to think about the topic or lesson content. After few times of practicing this type of instruction, students felt at ease to say what they think." (Tran, interview extract)

"[...] I think the positive side of providing students with an opportunity to learn reading through questioning and discussion over the reading context is to see how students were ready to do the pre-reading task." (Trang, interview extract)

"I found out that students could get themselves familiarized with the pre-reading task as a warm-up while they were given time to work in pairs and then present their part." (Linh, interview extract)

All of the teachers acknowledged the benefits of scaffolding students' reading comprehension through their actual teaching practices. The statements mentioned above indicate that scaffolding beginning with question-based tasks were believed to heighten students' reading and improve their higher-order thinking.

\section{B. Challenges of scaffolding}

Challenges reported by the teachers in this study were identified as the mixed-ability students' English proficiency, class size, time-consuming issue, and students' attitudes towards cooperation with the teacher.

\section{a. Mixed-ability students' English proficiency}

Three out of the six teachers said that mixed ability students' English proficiency was the most challenge while delivering reading passages. The following extracts illustrate their views.

"I found the difference in ability and knowledge of students in reading class is the most difficult thing. For low-achieving students, I had to use different way to help them focus to the main topic." (Diep, interview extract)

"The difficulty of scaffolding for students, I think, is the unequal level of students in the class. Some students find it hard to express their ideas to share with others as their words are limited." (Vinh, interview extract) 
"In a class where the students' proficiency is not equal, scaffold for students will be difficult." (Trang, interview extract)

\section{b. Class-size}

Class-size was perceived by the teachers as a challenge in introducing the text. Examples of this view are presented below.

"[...] Class-size actually influences how I begin a lesson. Some students can't get involved in discussing or talking about the topic before reading." (Tran, interview extract)

"[...] I think class-size to some extent makes me change some steps or activities in delivering the reading lesson." (Hanh, interview extract)

"[...] Class-size is only a minor part that prevents me from pre-teaching stage. While some good students can understand the before-reading questions, others can't do that as expected." (Trang, interview extract)

\section{c. Time-consuming issue}

All of the teachers claimed that time constraint was a real issue they encountered during instruction. For example,

"[...] For a reading text that I need to prepare, it takes a lot of time." (Diep, interview extract)

"In order to help students learn well, I need to invest much time preparing lectures. For example, using pictures or ask questions as warm-up activities before teaching reading to encourage them to share ideas takes time". (Vinh, interview extract)

"Students' attitudes towards collaboration with the teacher." (Linh, interview extract)

One teacher expressed her concern about students' attitudes towards working with the teacher. Linh commented:

"[...] The challenge I met with my students in reading class is that some students are not ready or willing to communicate with me. You know, everything does not always go as planned or as planned [...] Thus, scaffolding sometimes does not work. (Linh, interview extract) 


\section{Discussion}

This study indicates that the participating teachers had positive perceptions of scaffolding students' reading comprehension. The following section discusses the findings from this study in relation to the research question.

Research question: What are teachers' perceptions of scaffolding EFL students' reading comprehension?

The current study aimed to examine teachers' perceptions of scaffolding students' reading comprehension in high schools in the Mekong Delta, Vietnam. The findings show that the participating teachers understood the importance of scaffolding as a type of teacher support that promotes students to learn and develop reading skills, and obtain new knowledge in a more active learning space. In addition, the teachers perceived that providing instructional support could enhance teacher-student interaction. The findings from the questionnaire reveal that the teachers had positive perceptions of scaffolding despite varying degrees. Their perceptions support the literature that indicates scaffolding during instruction could increase students' skills performance in their learning process (Belland, 2014; Enyew \& Yigzaw, 2015; Hong \& Nguyen, 2019). These conceptualizations were reported through interview responses.

The findings from semi-structured interviews reveal some possible benefits of scaffolding in reading classes, namely two-way interaction, increased students' interest, active learning atmosphere, and anxiety reduction for students. With regard to the interaction between the teacher and students, this finding confirms Gibbons' (2015) claim that once students are provided support, they become active participants through collaborating with others. Awareness of providing students with support in reading instruction in order to heighten their interests, create active learning space or environment, and reduce anxiety suggests that the teachers can find ways to help students move forward and take ownership of their learning and construct new knowledge. This awareness is in line with the literature on scaffolding reading comprehension (Rodgers, 2017; Walqui, 2006), indicating that teacher scaffolding influences how students improve their understanding at higher levels and become gradual independence in accomplishing a given task. However, the participating teachers thought that the challenges of scaffolding in their teaching practice identified as mixed-ability students' English proficiency, class-size, time-consuming issue, and students' attitudes towards collaboration with the teacher. These insights allow the teachers to reflect on their reading instruction and tailor their instructional practices.

\section{Conclusions}

The findings of this study provide insights into teachers' perceptions of scaffolding students' reading comprehension. As the teachers perceived scaffolding as positive instructional tool to promote students' reading gains to align with the social view of 
learning, it appears that the release of responsibility or ownership students take is necessary and that teachers' perceptions may influence their roles and decisions in reading classes to provide timely support to assist students in building on new knowledge in critical and constructive ways. Once students are provided opportunities to involve in taking greater responsibility and participation in deepening reading skills for effective learning, teachers will create different types of instructional support and strategies to meet the students' learning needs. For the better quality of teaching reading, future research needs to focus more on teachers' professional development training workshops or seminars on how scaffolding can be integrated in reading contents. These continuing practices will help teachers foster their personal and professional expertise, thereby diversifying their reading strategies to make their classroom environment more interesting and interactive.

\section{Conflict of Interest Statement}

The authors declare no conflicts of interests.

\section{About the Authors}

Chau Ngoc Tran is a lecturer in English at Ca Mau Vietnam-Korea Vocational College. She is a master candidate in education, School of Foreign Languages, Can Tho University. Her research interests include teaching methodologies and reading skills.

Huan Buu Nguyen is Associate Professor, School of Foreign Languages, Can Tho University, Vietnam. His research interests include teachers' beliefs, teacher change, active learning, ESP, and curriculum planning.

\section{References}

Ankrum, J. W., Genest, M. T., \& Belcastro, E. G. (2014). The power of verbal scaffolding: "Showing" beginning readers how to use reading strategies. Early Childhood Education Journal, 42, 39-47.

Belland, B. R. (2014). Scaffolding: Definition, current debates, and future directions. In J. Spector, M. Merrill, J. Elen \& M. Bishop (Eds.), Handbook of Research on Educational Communications and Technology (4th Ed. ed., pp. 505-518). New York, NY: Springer.

Bernhardt, E. B. (2011). Understanding advanced second language reading. New York: Routledge.

Booth, D. (2012). Scaffolding during the formal assessment of young EAL learners: A New Zealand case study. Australian Review of Applied Linguistics, 35(1), 5-27.

Boyatzis, R. E. (1998). Transforming qualitative information: Thematic analysis and code development Thousand Oaks, California: SAGE Publications, Inc.

Eggen, P., \& Kauchak, D. (2001). Educational psychology: Windows on classrooms (5th Ed.). Upper Saddle, River, NJ: Merrill Prentice-Hall. 
Enyew, C., \& Yigzaw, A. (2015). Effects of teacher scaffolding on students' reading comprehension. Science, Technology and Arts Research Journal, 4(2), 263-271.

Fraenkel, J. R., Wallen, N. E., \& Hyun, H. H. (2012). How to design and evaluate research in education (8th Ed.). New York: McGraw-Hill Humanities.

Gibbons, P. (2015). Scaffolding language, scaffolding learning: Teaching English language learners in the mainstream classroom (2nd Ed.). Portsmouth, NH: Heinmann.

Grabe, W. (2009). Reading in a second language: Moving from theory to practice. Cambridge: Cambridge University Press.

Herawati, C., Gani, S. A., \& Muslim, A. (2020). The implementaton of scaffolding reading experience strategy in increasing students' comprehension. Journal of Language Teaching and Linguistics, 1(2), 102-113.

Hong, T. D., \& Nguyen, H. B. (2019). Teacher beliefs and practices of scaffolding students' reading comprehension through questioning at pre-reading stage. European Journal of Foreign Language Teaching, 4(2), 72-92. doi: https://dx.doi.org/10.5281/zenodo.3270743

Israel, S. E., \& Duffy, G. G. (2009). Handbook of research on reading comprehension. Madison Ave, NY: USA: Routledge Taylor \& Francis Group.

Lapan, S. D., \& Quartaroli, M. T. (2009). Research essentials: An introduction to designs and practices. San Francisco, CA: Jossey-Bass.

McKenzie, L. D. (2001). Scaffolding English language learners' reading performance. (PhD $\mathrm{PhD})$, Walden University.

Ministry of Education and Training. (2008). Teaching and learning foreign languages in the national education system from 2008 to 2020. Hanoi, Vietnam: Retrieved from http://tailieu.vn/doc/de-an-day-va-hoc-ngoai-ngu-trong-he-thong-giao-duc-quocdan-1331102.html.

Nguyen, H. B. (2014). Teacher change in science education in a Vietnamese university. (Ph.D.), Massey University, Palmerston North, New Zealand.

Nguyen, H. G. T., \& Nguyen, H. B. (2019). Teachers' perceptions about vocabulary instruction through flashcards at English language centers in the Mekong Delta city. i-manager's Journal on English Language Teaching, 9(3), 36-48.

Nguyen, T. C., \& Nguyen, H. B. (2020). Teachers' perceptions about using songs in vocabulary instruction to young language learners. Universal Journal of Educational Research, 8(6), 2678-2685. doi: https://dx.doi.org/10.13189/ujer.2020.080652

Nuttall, C. (2005). Teaching reading skills in a foreign language (2nd Ed.). Oxford: Macmillan Heinemann.

Pearson, P. D. (2009). The roots of reading comprehension instruction. In S. E. Israel \& G. G. Duffy (Eds.), Handbook of research on reading comprehension (pp. 1-31). New York: Routledge, Taylor and Francis Group.

Proctor, C. P., Dalton, B., \& Grisham, D. L. (2007). Scaffolding English language learners and struggling readers in a university literacy environment with embedded strategy instruction and vocabulary support. Journal of Literacy Research, 39(1), 7193. 
Reed, B., \& Railsback, J. (2003). Strategies and resources for mainstream teachers of English language learners (E. D. R. Service, Trans.).

Reynolds, D., \& Daniel, S. (2018). Toward contingency in scaffolding reading comprehension: Next steps for research. Reading Research Quarterly, 53(3), 363-373.

Richards, J. C., \& Schmidt, R. (2010). Longman dictionary language teaching and applied linguistics (4th Ed.). London, Britain: Pearson.

Rodgers, E. (2017). Scaffolding word solving while reading: New research insights. The Reading Teacher, 70(5), 525-532.

Salem, A. (2017). Scaffolding reading comprehension skills English Language Teaching, 10(1), 97-111.

Snow, C. E. (2002). Reading for understanding: Toward a research and development program in reading comprehension. Santa Monica: RAND Corporation.

van de Pol, J., Volman, M., \& Beishuizen, J. (2010). Scaffolding in teacher-student interaction: A decade of research. Educational Psychology Review, 22(3), 271-296. doi: https://doi.org/10.2007/s10648-010-9127-6

Vygotsky, L. S. (1978). Mind in society. Cambridge, MA: Harvard University Press.

Walqui, A. (2006). Scaffolding instruction for English language learners: A conceptual framework. The International Journal of Bilingual Education and Bilingualism, 9(2), 159-180.

Ward, M. O., Grinstein, G., \& Keim, D. (2015). Interactive data visualization: Foundations, techniques, and applications. New York: CRC Press.

Wood, D., Bruner, J., \& Ross, G. (1976). The role of tutoring in problem solving. Journal of Child Psychology and Child Psychiatry, 17, 89-100. 
Creative Commons licensing terms

Authors will retain the copyright of their published articles agreeing that a Creative Commons Attribution 4.0 International License (CC BY 4.0) terms will be applied to their work. Under the terms of this license, no permission is required from the author(s) or publisher for members of the community to copy, distribute, transmit or adapt the article content, providing a proper, prominent and unambiguous attribution to the authors in a manner that makes clear that the materials are being reused under permission of a Creative Commons License. Views, opinions, and conclusions expressed in this research article are views, opinions and conclusions of the author(s). Open Access Publishing Group and European Journal of English Language Teaching shall not be responsible or answerable for any loss, damage or liability caused in relation to/arising out of conflict of interests, copyright violations and inappropriate or inaccurate use of any kind content related or integrated on the research work. All the published works are meeting the Open Access Publishing requirements and can be freely accessed, shared, modified, distributed and used in educational, commercial and non-commercial purposes under a Creative Commons Attribution 4.0 International License (CC BY 4.0). 